\title{
Robust cellular network for Rural Telephony in Southern Nigeria
}

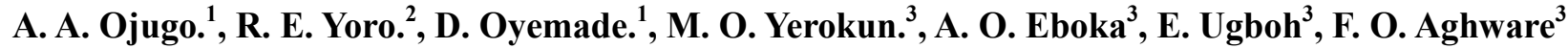 \\ ${ }^{1}$ Department of Mathematics/Computer, Federal University of Petroleum Resources Effurun, Delta State \\ ${ }^{2}$ Department of Computer Science, Delta State Polytechnic Ogwashi-Uku \\ ${ }^{3}$ Department of Computer Science, Federal College of Education Technical Asaba
}

\section{Email address:}

ojugo_arnold@yahoo.com(A. A. Ojugo.), aojugo@mail.fupre,edu.ng(A. A. Ojugo.), rumerisky@yahoo.com(R. E. Yoro), davidoyemade@yahoo.com(D. Oyemade.),an_drey2k@yahoo.com(A. O. Eboka), agapenexus@hotmail.co.uk(M. O. Yerokun), ugbohh@gmail.com(E. Ugboh), aghwarefo@yahoo.com(F. O. Aghware)

\section{To cite this article:}

A.A. Ojugo., R. E. Yoro., D. Oyemade., M. O. Yerokun., A. O. Eboka, E. Ugboh, F. O. Aghware. Robust Cellular Network for Rural Telephony in Southern Nigeria. American Journal of Networks and Communications. Vol. 2, No. 5, 2013, pp. 125-132. doi: 10.11648/j.ajnc.20130205.12

\begin{abstract}
The paper identifies the state of telecommunication's services and its growth cum economic relevance in Nigeria, while proffering a cost-effective and less problematic telephone network that is readily affordable and available to the poverty-stricken populace predominant in rural areas. The design and implementation of an efficient, robust network based on existing Global Satellite for Mobile communication) cum Code Division Multiple Access, as means to cater and provide for telecommunications in rural Delta State in Nigeria. A major hinderance to the provision of such services/facilities in rural area for decades, has been the high operational cost and little profit margins. Thus, the robust network aims to create an effective, affordable option for such rural and semi-urban settler; while on the part of operators, a system with minimal cost to implement, deploy and maintain for Delta State Senatorial District in Delta State, Nigeria, is used as the case study to test-run the analysis and design of such a novel cellular network.
\end{abstract}

Keywords: Topography, Robust, Telephony, Tele-Penetration, Tele-Density

\section{Introduction}

Telephony in rural Nigeria and those of developing nations have been a recurring subject - as a country's economic growth/development as measured via its gross national product, is strongly correlated to communication (namely telephone density and her tele-penetration - a function of the number of lines per 100 persons). It is common knowledge that rural telecommunication users do not generate same amount of traffic and revenue as their urban counterpart, which tends to lower the incentives to invest by many operators. The cost of wiring a vast area for low data traffic causes providers to delay or ignore service provision to such areas except with government's strict intervention and regulation[1].

The increased interest worldwide in the growth of rural areas has led to feasibility studies towards the provision of telecommunication services in rural areas for national, economic and social interactions. The International Telecommunications Union (ITU) has defined a rural area as "that which has one or more of these feats: (a) area's primary source of power is scarce, unavailable, uncoordinated and scattered, (b) Local scarcity of qualified technical personnel, (c) Topographical conditions exists (like mountains etc) hindering construction of switching cum transmission system, and (d) Economic constraint on investment that renders service non-profitable due to high-cost construction and maintenance, especially if the cost is borne by the rural zone settlers alone [1].

For the purpose of providing telecommunication services, ITU and CCITT (International Telephone and Telegraph Consultative Committtee), an arm of ITU - has set these rules for the classification of an area as rural [1]: (a) Average subscriber density of $50 \mathrm{~km}$ maximum, (b) subscribers range from about $5 \mathrm{~km}$ to $50 \mathrm{~km}$ and (c) to be served communities are isolated with maximum of 1000 subscribers. Hence we note, rural telephony is defined as provision of telecomm services in sparsely populated areas with economic and geographical disadvantages.

Telepenetration measures the user percentage covered by 
telecomm services in a country's entire population; while teledensity measures percentage of such users with telephone lines. The importance of rural communication in Nigeria is continually demonstrated via NCC (Nigerian Communications Commission) stakeholders' forum that identifies the existence of rural dwellers, rural-urban dichotomy, need to bridge such divide via service provision extended and enforced to underserved and unserved areas. Africa's telecomms huge and steady growth (with Nigeria in focus) this last few years, has been dramatic with highlights for African market that saw a growth rate of $66 \%$ in 2005 (the highest ever experienced in any world region) and 150 million subscribers milestone exceeded in 2006, 12years after its first launch in Africa [7].

In Nigerian, Zain came in 2001 as Buddie (and later rebranded as Vodafone, Celtel and Airtel) and now has a customer-base of over 12million. Next, came MTN in 2003, now with over 16million users; Globacom in 2005 now with over 10million and lastly, Etisalat, now with over 8million users. Thus, GSM penetration in Nigeria is presently over 40million in the past 10years. Despite this progress, the extent of the geographical telepresence of GSM and the technology itself, is still among the lowest.

Lastly, most territories in the North, South West, South East and the swampy coastal areas of Niger Delta are yet to be properly served and covered by such telecomm operators. This is not unconnected with the population density in such regions, the rural/urban dichotomy as well as in some cases, the unfriendly terrain that makes the huge investment of terrestrial infrastructure grossly unprofitable.

\section{Literature Review}

There are many issues to be defined when designing rural telecommunications network - all of them of varying importance, and falls into three categories: (a) Geopolitical deals with the areas development level based on its social, educational, political and economic history, (b) Economic defines the inital investment required to deploy such communication services via installation of facilities and equipment in such a remote region, its operational cost and the user's revenue generating capacity - so that such a service can be provided for, supported financially and keeping its subsidies to a negligible minimum, and (c) Technical - deals with availability of technology to implement the design, legal and regulatory framework, rural communities'size and the expected traffic, type of services and availability of technical workforce [8]. However, study centers on technical issues involved in analysis, design and deployment of a robust network for rural telephony.

\subsection{Wireless Technology}

With application of electronic data systems in every facet of our daily endeavor, it becomes increasingly bothersome to be tethered by wires. Thus, wireless technology comes to the rescue with these merits: (a) low-cost of devices, (b) broadcast same data to many locations at same time, (c) easily deploy in hostile and difficult environment, and (d) mobile communication. Its demerits: (a) lesser data rates, (b) operates in less controlled environ, (c) more susceptible to interference, eavesdropping and/or noise, and (d) lesser reusable frequencies than in the case of guided wired media.

Wireless Technologies are grouped as thus:

1. 1st Generation - such as AT and T's advanced mobile phone services, commonly used in South America, China and Australia. Its system comprise of three basic devices: a mobile unit, base transceiver and mobile telephone switching office (MTSO). The mobile unit interacts with the trasceiver; which then interacts with MTSO. The MTSO controls all trasceivers and connects calls to public telephone network. Its demerit is its limitation to reuse same frequency in various communication, as its signals if not constrained, interferes with one another (even when separated geographically). It supports a very large number of communications simultaneously and needs spectrum conservation. It has two $25-\mathrm{MHz}$ bands, one transmits from station to mobile unit and the other transmits from the mobile terminal to the base station. Each is split in two, to ease and encourage competition. Its channels are also spaced $30 \mathrm{kHz}$ apart, with total of 416 channels for an operator. 21channels for call control, and the other 395 for calls.

2. 2nd Generation - GSM and CDM/FDM access (code/frequency division multiplexing) falls into this generation. GSM was developed to solve the incompatibility of cellular technologies so that a number of subscriber terminals can be used. Its basic feats includes: Subscriber Identity Module (SIM) a portable smart-card like, plug-in device that stores a subscriber's identification number, the networks the subscriber is authorized to use, encryption keys, and other information specific to the subscriber. Each terminal is generic until a SIM is inserted. Thus, the SIMs roam but not the terminal or subscriber device. Its transmissions are encrypted with A5 cipher from the user to the base trasceiver and another A3 cipher is used to authenticate calls so that it is private. GSMs support data and image services based on ISDN (Integrated Service Digital Network) model with user data rates upto $9.6 \mathrm{kbps}$.

Multiple Access like GSM - uses digital method to enhance advanced call processing feats. 1st generation systems were successful but its use was constrained by spectrum. Thus, there is a premium on its efficiency use of spectrum. Thus, multiple access details how the spectrum can be divided among active users in its planned systems via four methods: frequency division multplexing FDM, space division multiplexing SDM, time division multiplexing TDM and code division multiplexing CDM.

Besides pure form channel splitting in multiple access, 
there can also be hybrids. For example, GSM uses FDM to divide the allotted spectrum into 124 carriers and each carrier is then split into eight parts using TDM so that the number of potential users in any one cell is potentially enormous and any subscriber in any area can enter the cell. In addition, lots of roamers can show up and fortunately, the system can identify the number of customers who are in a given cell at any time and have their terminals registered with the system in a modest form. Its only problem is how to determine active users in a cell and assigning them to vacant subchannels. It is resolved with MTSO as mobile terminal, entering a cell via handover is quickly allotted a channel directly via MTSO. The access method to use is depedent on the system to be designed, factors or constraints in the natural environment among others. Many providers now sign up for CDM as it offers more/additional feats.

3. 3rd-Generation offers mobile unit and personal communication services incorporating into a set of standard, services that a handheld terminal can support (voice, data, image, video). Example is Motorola's Iridium project capable of paging, data and facsimile in hand-held phones/pagers worldwide.

\subsection{Satellites}

Satellites are characterized by the orbit they keep into three (3) basic types namely [5, 6]:

1. GeoSynchronous (GEOS) circularly orbits at 22,300miles above, rotating at earth's equatorial planes, exactly same angular speed as the Earth. So, it rotates at same spot and speed above the equator. Its merit as a stationery satellite relative to earth are: (a) averts frequency change due to relative motion of satellite on earth, (b) simplified tracking by its earth station, (c) its height allows it communicate with roughly a fourth of earth and (d) its assigned frequency covers very large area. Its demerits also includes: (a) weak signal strenght due to height, (b) polar areas and hemispeheres are poorly served, (c) with signal traveling at light speed, delays exist, computed as $(2 * 22300) / 186000=0.24 \mathrm{sec}$. Thus, stations that receive/resend, delay is longer, (d) for TV broadcast, application to coverage area is wasted and special spots and steer beam antenna is used, to restrict coverage area and control footprint.

2. Highly Elliptic Orbit Satellite (HEOS): At low angles, satellite signals are easily obstructed by hills, mountains and buildings. HEOS is used to orbit elliptically inclined with respect to equator. At farthest apogee of 24856miles over Northern hemisphere and $500 \mathrm{~km}$ at its perigee in Southern, to provide good coverage. Thus, it spends $12 \mathrm{hrs}$ over Northern sphere and with its orbit elliptic, multiple staellites are needed for 24-hr coverage. The extent its apogee is greater than geosynchronous altitude allows signal attenuation and/or loss to expand.

3. Low-Earth Orbit Sats (LEOS) is constellation of inexpensive satellites orbiting $200-700$ miles above earth - creating lightsats of stronger cum better signals, better localized coverage area and conserve spectrum. We have two LEOS namely: Small LEOS (works at frequency below $1 \mathrm{GHz}$ using $5 \mathrm{MHz}$ to support data upto $10 \mathrm{kbps}$ used in paging, tracking and low-rate messages) and Big LEOS (with frequency above $1 \mathrm{Ghz}$ to support data a few mbps. It offers same services as small LEOS alongside voice and positioning services. Many of it is needed to provide $24-$ hrs coverage.

\section{Materials / Method}

\subsection{Study Purpose/Objective}

Study aims to design a robust telephone network to aid rural telephony; and via this, improve Nigeria's socio-economic and gross national product with increased tele-penetration density - for Delta North Senatorial District in Nigeria - estimated as $3984.34 \mathrm{~km} 2$ in fig 2 using a scale of $1: 100$.

\subsection{Proposed Satellite System}

Satellite technologies employed in rural telephony needs a different analysis of its technical parameters - becasue the chosen satellite network technology heavily influences choice of a user's terminal (small earth stations) feats. its overall costs and lifetime. A remote user can access a private switch telephone network (PSTN) via satellite in any of two methods: (a) Direct access allow users to transmit from mobile terminal directly to the satellite, and (b) Indirect access allow users transmit from wired/wireless land line (WLL) user terminal via VSAT terminal, private branch exchange (PBX) and a GEOS as in fig. 1.

This study adopts an indirect user access approach that is seamlessly integrated with TIW FlexiDAMA II and VSAT network into a CDMA-2000 wireless system (CDMA will serve as WLL segment patform for our robust network and the reason for our choice as in sub-section

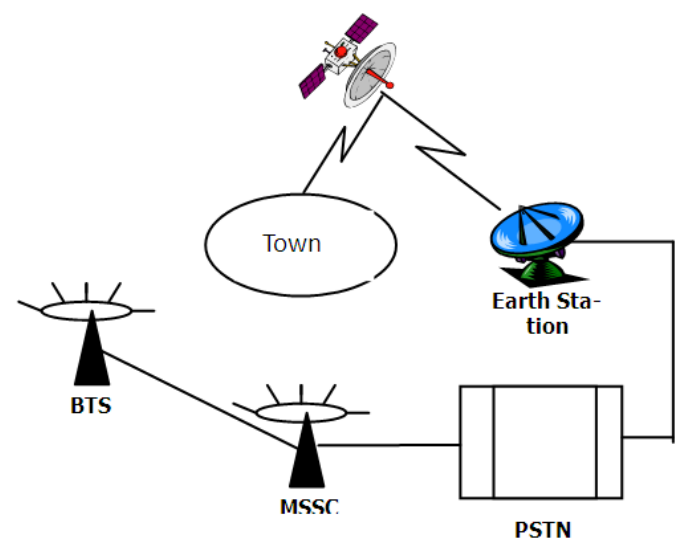

Fig. 1: Direct user access to Satellite 
Other reasons for CDMA as suitable choice are:

a. Voice compression on the satellite link at rates as low as $9.6 \mathrm{kbps}$ (with fax, image, video and data)

b. Uses a robust-forward error correction coding on a very-narrow band, which also has full-digital operation capabilities on the satellite access.

c. GPS-derived frequency and timing references

d. Demand Assigned Multiple Access for all voice calls that allows for roaming and allows just active users to be authenticated on handover, registering of subscriber terminals as they roam and random access channel allocation directly by MTSO via a control message that assigns the user terminal a dedicated channel when a conversation or data transfer is necessary.

e. True voice activation so that satellite energy is only used during voice peaks.

f. Full-mesh with distributed call-routing operation so that calls originating from any station is routed directly to the destination station without having to be routed via a hub, gateway or another station - and maximize efficiency of the satellite links as well as minimize propagation delay.

\section{Planning / Implementation}

A cost-effective solution will result in proper radio network planning with a focus on service delivery, quality, coverage and capacity [9], discussed under:

\subsection{Pre Planning Coverage and Capacity}

Involves a theoretical coverage and capacity plans. In theory, as the cells are split into smaller sizes - interference received from cell frequency reuse will remain; and irregular propagation and non-circular cell shapes will lead to greater interference being received from the surrounding cells that all use the same channel set [10]. A way to reduce the level of interference is to use a directional antenna at base station - each antenna illuminates a sector of the cell, and a separate channel set allocated to each sector.

Study adopts 3 -sectored, triangulation cell design of 7-cell repeated pattern ( $\mathrm{N}=7$ trunking efficiency) - resulting in the overall requirement of 21 channels sets. The base station to be used are 3-sectored and each sector (cell) will cover a range of $4.0 \mathrm{~km}$. Thus, area covered by site is as thus:

$$
\text { Area Covered }=\frac{3 \phi}{360} \pi R^{2}=\pi R^{2}
$$

$\phi=$ sector angle $120^{\circ}, \mathrm{R}=$ One antenna coverage range $=$ $(4 \mathrm{~km})$. Area $\pi R^{2}=3.142 * 4^{2}=50.28 \mathrm{~km}$

Total number of sites to be setup is given by:

$$
V=\frac{\text { Coverage Area }}{\text { Cell sites coverage }}=\frac{3984.34}{51}=78.124
$$

Thus, the total average number of cell sites to be constructed are approximately 78 sites.

\subsection{Bandwidth Limit to Subscribers}

Cell layout in fig 4 helps formulate number of radios to be used in the plan via the simple equation below using the parameters in a 3 -sector, GOS $=0.1$ :

Delta North Senatorial District area $=3984.34 \mathrm{~km}$.

Population projection for $2012=10,820,123$

Average radius of cells $(\mathrm{km})=4$

Number of radio channels in each $n_{c}=93$

Number of Subscribers per Channel $=28$

Number of Subscriber $/$ Cell $=2604$

$\mathrm{N}_{\mathrm{c}}$ depends on what cell repeat pattern is used and spectrum allocated to the service [10]. We use a wireless CDMA on a cellular network with dynamic assignment cum trunking - interpreted as channel gain [10] allowing 28 -subscribers individual access to one channel. Number of subscribers supported by each channel in the cells is multiplied by factor (30). With channel gain, number of subscribers on each cell is given by:

$$
\text { Subscribers }=\frac{\text { Base station GOS }=0.01}{\text { subscriber Erlang } 0.03}=\frac{0.1}{0.03}=3.333
$$

$\mathrm{n}_{\mathrm{c}}=30 *$ Subscribers $=30 * 3.333 \rightarrow 99.9 \approx 100$

Total Subscribers supported simultaneously:

$=10 \pi \mathrm{n}_{\mathrm{c}} *$ Subscriber/Cell

$=10 * 3.142 * 100 * 2604=8,181,768$ subscribers

Thus, the proposed network can approximately cater for $8,181,768$ subscribers at same time in with effective service quality. These result shows that sparsely populated areas are easier to serve. If each subscriber has an average call and holding time of 6-calls/daily at an average of $3 \mathrm{mins}$ (180secs) duration, as it is unlikely for a user or any subscriber to talks for $24 \mathrm{hrs}$, generated traffic tends to bunch up - at busy (peak) hours and will fall drastically as more users try to access the network [10]:

$$
\text { Erlang }=\frac{\text { Calls } / \text { Day } * \text { Duration }}{\text { Mins } * \text { Hrs } *}=\frac{6 * 180}{60 * 60 * 4}=0.125
$$

Erlangs/Subscriber $=0.125$ Erlangs $/$ subscriber.

\subsection{Site Surevey and Choice}

Radio site selection criteria consists of:

a. Location chosen by propagation analysis

b. Availability of capacity existing sites

c. Site compatibility

d. Environmental and planning factors

Sites in the nooks of a Delta North Senatorial District are determined considering these criteria [11]: (a) buildings and other structures can be used as suitable antennas system erection sites, (b) accounting for effects on coverage by physical obstruction so as to ensure site stability, (c) good radiation pattern via sufficient height for antenna installation and avoid obstruction of the transmitted signals, (d) provision of service to required area, and (e) centrally 
located sites to ensure omin-direction of radiation pattern for minimum coverage area.

The use of the highest point or available site is not usually considered the best option as it degrade the services, due to co-channel users. The choice of site is an interactive process that is repeatedly computed with several constraints and parameters checked to validate as well as yield an optimal result or choices of selected sites [12].

\subsection{Propagation Analysis of Site Location}

For radio site choices, we need precise locations of construction, bearing in mind feats of Delta North Senatorial District, which are as follows:

$\checkmark \quad$ Rural area in focus, is not connected to national power grid - though work is currently in progress

$\checkmark \quad$ Buildings within semi-urban and urbanized areas of the district are bungalows and storey buildings that are quite high (between $5-8 \mathrm{~m}$ ).

$\checkmark \quad$ Its land mass is covered by valleys and trees of various heights that can block out signals.

$\checkmark \quad$ Settlers are predominantly farmers, with clusters and handful of civil and public servants.

Via propagation analysis, an average of 78-sites is selected for effectively coverage of the said District. Each selected cell site coordinate and elevation were taken using the Global Positioning System (GPS). Its readings are as shown in Table 1.

\section{Network Cell Structure}

Figures 2(a), (b), (c) and (d) shows the maps of all the Local Government Areas in Delta North Senatorial District. The cell design structure layout are as seen in fig 3 further explained in tables 1 that shows the feats of each cell site.

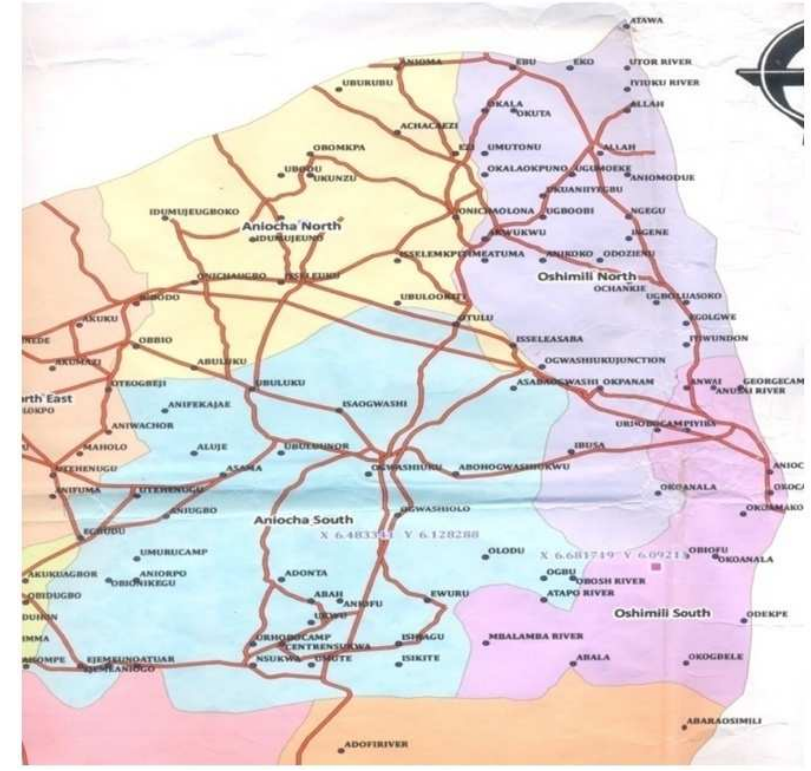

Fig 2a: Map of Oshimili North and South, Aniocha North and South

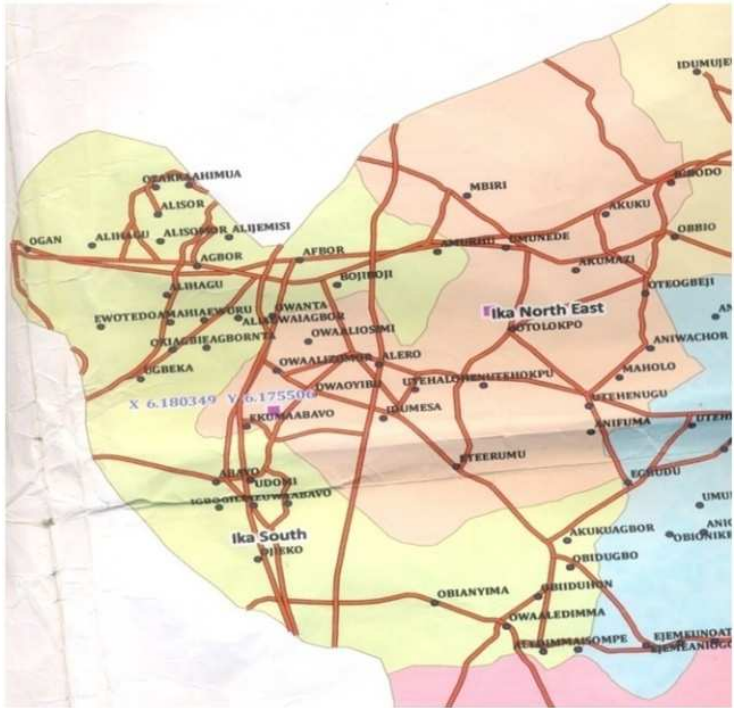

Fig 2b: Map of Ika North, North East and South

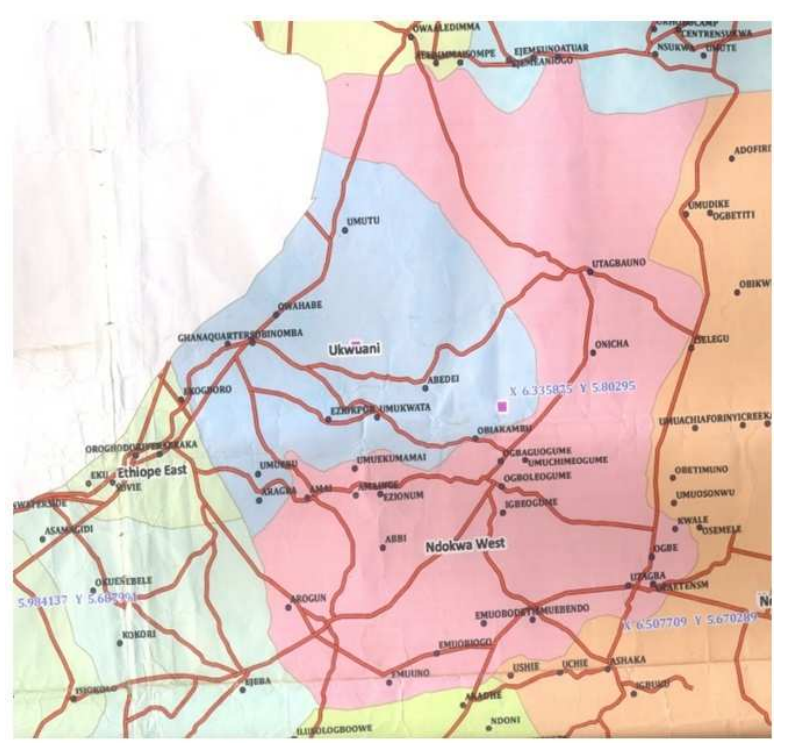

Fig 2c: Map of Ndokwa West and Ukwauani

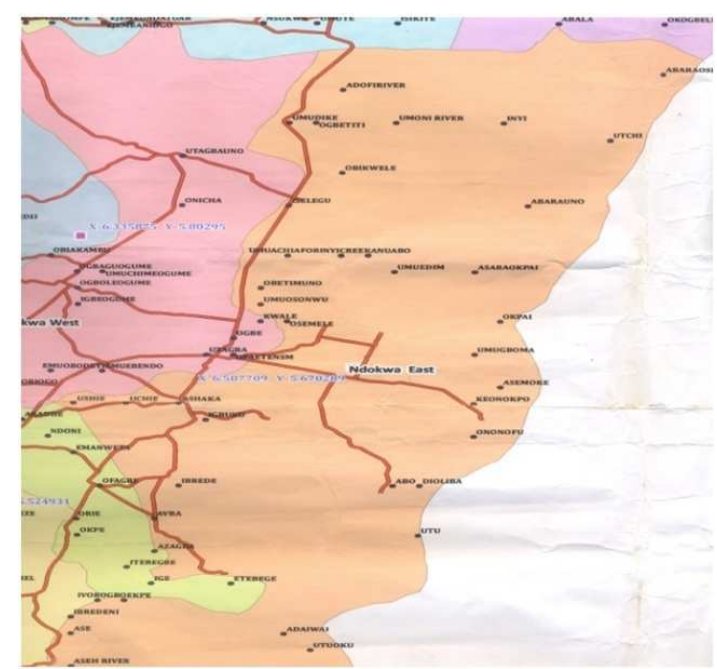

Fig 2d: Map of Ndokwa East and Ndokwa West 
From Fig. 3, each base transceiver station (BTS) in the implementation of the robust telephony is connected to its corresponding zone's mobile telephone switching office (MTSO) namely: Agbor, Ogume, Akumazi, Amai, Ogume, Atuma, Ubulu, Otulu, Asaba and Igbuku respectively. Each zone's MTSO is connected to the PSTN in Ubulu-Uku (as the central hub) with an $8 \mathrm{XE} 1$ protected link; while the
BTSs in each zone is connected to its corresponding MTSOs with the 2XE1 transmission link as in fig 4. Distance between each BTS and its corresponding MTSO lie between $8.6 \mathrm{kms}$ to $19.3 \mathrm{kms}$; while the corresponding distances between MTSOs in each corresponding zone and the PSTN at Ubulu-Uku lies between $15.78 \mathrm{kms}$ and $102 \mathrm{kms}$ as the case may be.

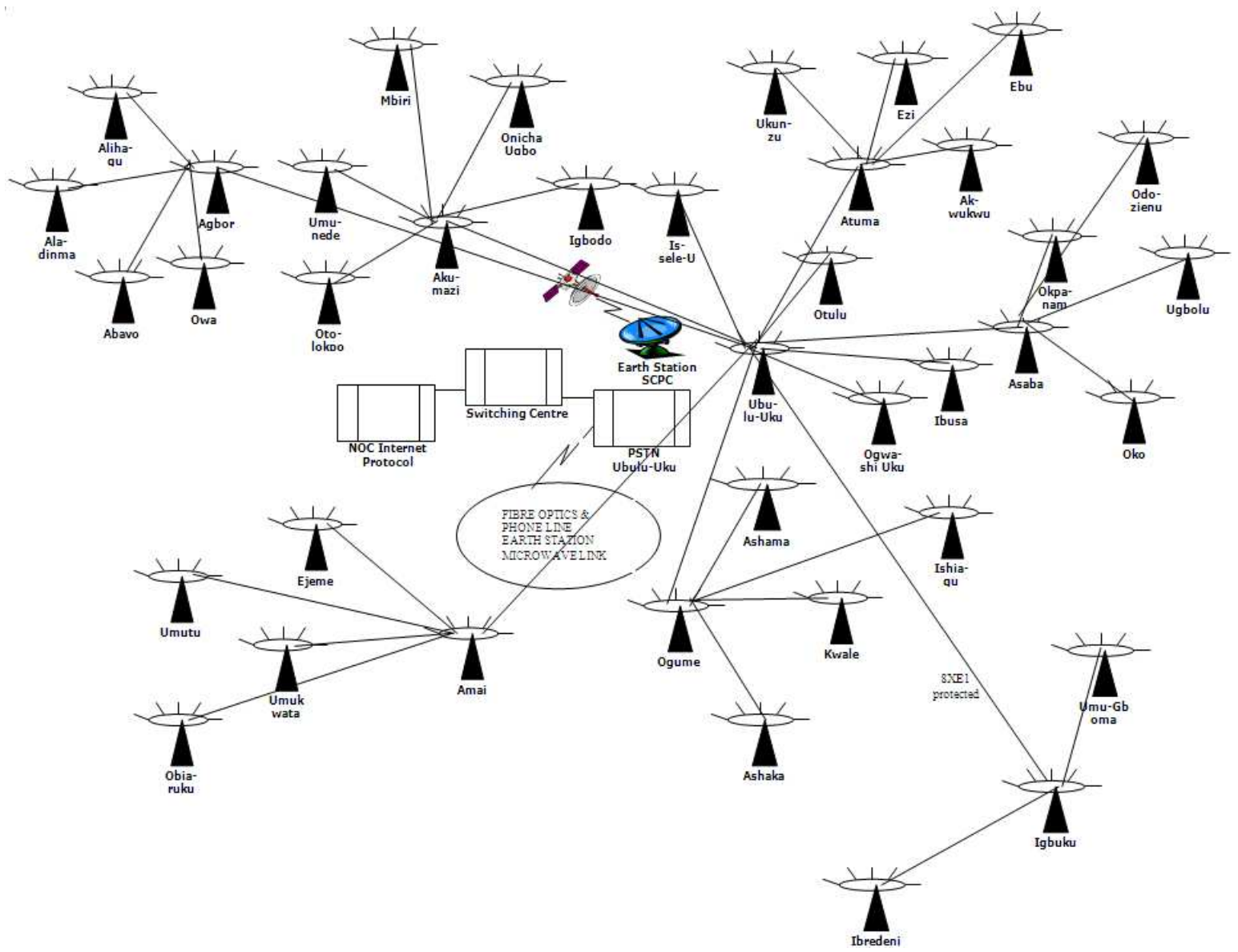

Fig 3: Cell sites and MTSOs for the Robust Telephony for Delta North

Table 1: Selected Cell Sites with Town, Villages and Camps covered in Delta North Senatorial District

\begin{tabular}{|c|c|c|c|c|}
\hline Location & Height & Latitude & Longitude & Areas Covered \\
\hline Abavo & 203 & 6.180330 & 6.095506 & $\begin{array}{l}\text { Abavo, Udomi, Ekuma, Idumuogbo, Ekwuezie, Iyemeni, Igbogili, Azu-Owa, Ojieko, } \\
\text { Ete-Erumu, Idumesa, Uteh-Okpu, Oyoko, Obi-Anyima, Obiduhun }\end{array}$ \\
\hline Agbor & 154 & 6.089341 & 6.200879 & $\begin{array}{l}\text { Agbor, Agbor-Obi, Boji-Boji, Obiliehen, Owanta, Emuru, Aliowa-Agbor, Agbor-Nta, } \\
\text { Ottah, Obeihem, Ighobe, Ottah }\end{array}$ \\
\hline Aladinma & 102 & 6.307903 & 6.089131 & $\begin{array}{l}\text { Aledinma, Owa-Aledinma, Obi-Anyinma, Obi-Iduhun, Obi-Ugbo, Ejeme-Atua, } \\
\text { Isomkpe, Ejeme-Uno, Ejeme, Isi-Nkita }\end{array}$ \\
\hline Alihagu & 120 & 6.068206 & 6.240564 & $\begin{array}{l}\text { Ogan, Alihagu, Owanisua, Alisor, Alisomor, Ozarra, Ahimua, Alijemisi, Omumu, } \\
\text { Ozo-Anugogo, Ewuru, Ewotedo, Ewuru, Amahia }\end{array}$ \\
\hline Akwukwu & 167 & 6.488999 & 6.389034 & Akwukwu, Onicha-Olona, Ugbo-Obi, Anikoko, Issele-Mkpitime \\
\hline Akumazi & 157 & 6.380023 & 6.312250 & Akumazi, Uteh-Ogbeje, Anifaka-Eje, Aniwachor, Ali-Ije, Uteh-Alo, Obbio \\
\hline Anifuma & 132 & 6.310719 & 6.206131 & $\begin{array}{l}\text { Anifuma, Uteh-Enugu, Maholo, Uteh-Enugu, Ani-Ugbo, Umuru-Camp, Aniokpor, } \\
\text { Ekuku-Agbor, Ete-Erumu }\end{array}$ \\
\hline Asaba & 187 & 6.524384 & 6.154839 & Asaba, Okpanam Camp, GRA-Phase, Iyiwudon, Anusai, Urhobo Camp \\
\hline
\end{tabular}




\begin{tabular}{|c|c|c|c|c|}
\hline Location & Height & Latitude & Longitude & Areas Covered \\
\hline Ashaka & 164 & 6.507700 & 5.670289 & $\begin{array}{l}\text { Uchie, Ashaka, Igbuku, Emanweta, Ibrede, Ofagbe, Ellu, Aradhe, Ndoni, Emu-Arade, } \\
\text { Emu-Ebendo, Ushie, Avba, Azagba, Emu-Uno, Emu-Obiogo, Emu-Obodeti, } \\
\text { Emu-Ebendo }\end{array}$ \\
\hline Atuma & 102 & 6.399902 & 6.209034 & Atuma, Issele-Mkpitime, Isa-Issele, Anikoko, Mkpitime \\
\hline Ebu & 205 & 6.500001 & 6.779021 & Ebu, Eko, Illah, Okpuno, Atawa, Utor, Iyiuku, Ugomuoke, Aniomodue, Ngegu \\
\hline Ejeme & 132 & 6.387002 & 6.199012 & Ejeme, Ejeme-Aniogor, Ejeme-Uno, Atua \\
\hline Ezi & 203 & 6.488933 & 6.600701 & Ezi, Achara-Ezi, Umutonu, Ezi-Umuodara, Ukanyi-Egbu, Umutonu \\
\hline Eziokpor & 187 & 6.285399 & 5.799824 & $\begin{array}{l}\text { Eziokpor, Abedei, Umukwata, Abbi, Arogun, Emu, Emu-Uno, Emu-Obiogo, } \\
\text { Emu-Obodoeti, Aragba, Umu-Ebu, Emu-Obendo, Umu-Ekumai, Amainge, Ezionum, } \\
\text { Umu-Ekukumai, Amai, Ekogboro }\end{array}$ \\
\hline Ibredeni & 203 & 6.244598 & 5.476509 & $\begin{array}{l}\text { Ibredeni, Asaba-Assa, Ikpede, Onya, Utu-Oku, Etebege, Avba, Ase, Adaiwa, Utu-Ocha, } \\
\text { Ivorogbo, Ekpe, Ige }\end{array}$ \\
\hline Ibusa & 198 & 6.498932 & 6.024820 & Ibusa, Achala, Aboh-Ogwashi, Achalla-Camp, Ute, Nkpikpa, Aboh, Umuehea, \\
\hline Igbodo & 192 & 6.305875 & 6.320010 & Igbodo, Ekwuoma, Emuhu, Amurhu, Akuku, Obomkpa, Obbio-Ozili, \\
\hline Ishiagu & 190 & 6.681719 & 5.600113 & Ishiagu, Isikite, Umute, Nsukwa, Umoni, Ukwu, Abah, Aniofu, Nsukwa, \\
\hline Issele-Uku & 178 & 6.318023 & 6.312250 & Issele-Uku, Idumuje-Uno, Ukunzu, Ugbodu, Obomkpa, Igbodo \\
\hline Kwale & 213 & 6.507709 & 5.690469 & $\begin{array}{l}\text { Kwale, Utagba, Umu-Osonwu, Osemele, Obetim-Uno, Opaetenasie, Umu-Achiafor, } \\
\text { Inyi Creeks, Anuabo, Umu-Edim, Ogbe, }\end{array}$ \\
\hline Mbiri & 180 & 6.278341 & 6.520187 & Mbiri, Umunede, Akuku, Otuocha, Mbiri-Iba, Umu-Anatum, \\
\hline Obiaruku & 200 & 6.200180 & 5.745092 & Obiaruku, Obinomba, Ebedei, Ighobe, Utagba-Uno, Amai, Ikolobie, Obi-Ukwuole, \\
\hline Odozienu & 200 & 6.355132 & 6. 400231 & Odozienu, Ingene, Anikoko, Aniocha Camp \\
\hline Ogume & 187 & 6.325875 & 5.789253 & $\begin{array}{l}\text { Ogume, Igbe-Ogume, Umu-Osonwu, Obetim-Uno, Ogbagua-Ogume, Obiakamba, } \\
\text { Ogbole-Ogume, Umudim-Ogume, Emu-Obiogo, Emu-Obodoeti, }\end{array}$ \\
\hline Ogwashi & 205 & 6.483341 & 6.128288 & Ogwashi-Uku, Azagba-Ogwashi, Isa-Asse, Aboh Ogwashi, Nkala-Ofu, \\
\hline Oko & 235 & 6.681719 & 6.092131 & Oko-Anala, Oko, Oko-Camp, Obiofu, Abala, Odekpe, Otuocha, Akwuebulu, \\
\hline Okpanam & 172 & 6.680913 & 6.175504 & Okpanam, Anwai, George camp, Azungwu, Abara-Oshimili, Mbalamba \\
\hline Onicha Ugbo & 190 & 6.388023 & 6.245220 & Onicha-Ugbo, Idumuje-Ugboko, Igbodo, Abukuluku, Uta-Ogbeje, Anifaka-Eje \\
\hline Otolokpo & 151 & 6.303341 & 6.200187 & Otolokpo, Uteh-Aloh, Uteh-Okpu, Utagba-Ogbe, Utagba \\
\hline Otulu & 241 & 6.276502 & 6.178034 & Otulu, Ubulu-Okiti, Issele-Azagba, Azagba-Ogwashi, Edo-Ogwashi \\
\hline Owa & 202 & 6.199802 & 6.189012 & $\begin{array}{l}\text { Owa, Owa-Oyibo, Owa-Alero, Owa-Alisor, Okiagbie, Igbanke, Railway Village, } \\
\text { Owa-Aladinma, Owa-Ofie, Ugbeka, Ekuku-Agbor, Aledinma, Okiagbie, } \\
\text { Owa-Aledinma, Obidi-Ugbo }\end{array}$ \\
\hline Ubulu-Uku & 198 & 6.387121 & 6.203980 & $\begin{array}{l}\text { Ubulu-Uno, Ubulu-Uku, Edo-Ogwashi, Isa-Ogwashi, Ani-Ugbo, Umuru, Aniokpo, } \\
\text { Egbudu, Ali-Ije, Abah-Uno }\end{array}$ \\
\hline Ukunzu & 167 & 6.399033 & 6.589921 & $\begin{array}{l}\text { Ukunzu, Uburubu, Anioma, Achara-Ezi, Ubodu, Ukala, Ukala-Okpuno, Uku-Anyiegbu, } \\
\text { Okuta }\end{array}$ \\
\hline Ugbolu & 154 & 6.601129 & 6.340012 & Ugbolu, Egoigwe, Asoko, Ochankie, Iyiwudon \\
\hline Umudike & 190 & 6.523779 & 5.819903 & $\begin{array}{l}\text { Ogbe-Etiti, Onicha, Utagba-Uno, Umudike, Obikwele, Iselegu, Umoni, Inyi, Utchi, } \\
\text { Adofi-Camp }\end{array}$ \\
\hline Umutu & 190 & 6.392853 & 5.990824 & $\begin{array}{l}\text { Umutu, Owahabe, Umuaja, Umu-Isele, Ojeta, Ogbe-Ufie, Obi-Ukwuole, Obi-Ngene, } \\
\text { Oliegogo,Umuisele, Ojeta, }\end{array}$ \\
\hline Umukwata & 162 & 6.185301 & 5.799204 & $\begin{array}{l}\text { Umukwata, Ebedei, Ebedei Uno, Ebedei Waterside, Owa-Abbi, Abbi-Uno, Akuku-Uno, } \\
\text { Ogbe-Ufie }\end{array}$ \\
\hline Umu-Gboma & 198 & 6.632490 & 5.676655 & $\begin{array}{l}\text { Umu-Gboma, Asemoke, Keonokpu, Ononofu, Dioliba, Utu, Okpai, Asaba-Okpai, } \\
\text { Abara-Uno, Abo, Issele-Asemoke, Essem }\end{array}$ \\
\hline
\end{tabular}




\section{Recommendation and Conclusion}

From the study, these recommendations were made:

$\checkmark \quad$ To operate optimally, network requires adequate power supply. Solar energy, compressed wind and gas options may prove to be a better choice. If adequate connection to the national grid exists, it will then serve as backup.

$\checkmark \quad$ State Governments should investment and deploy such infrastructure to underserved and unserved regions. At completion - handed over to private operators for management and maintenance, with such operators given adequate time to recoup and payoff initial investment via initiating a low-tarrif plan as incentive to trigger interest of dwellers.

$\checkmark \quad$ An appreciable tax reduction given to operators willing to deploy such network to rural areas - so as encourage participation from them as well as wider coverage within the shortest time.

\section{References}

[1] Osuagwu, E., Anyanwu, E and Amaeshi, L., (2003). Computer-based radar for improved military security surveillance in Nigeria, Computer Sci. and Application, 9(1), pp.71-81.

[2] Helgert, H., (1991). Integrated services digital net: Architecture, protocols and standards, Readings: MA: Addison-Wesley.

[3] Zymanski, W and Zymanski, F., (2004). Introduction to Computer System, McGraw Hill Publishers, New York.

[4] Martins, J.A., (1990). Telecommunications and computer, Prentice Hall publishers, New Jersey.

[5] Abraham, M., Jajodia, S and Podell, H., (1995) Information security, IEEE computer society press, Los Alamitos, CA.

[6] Hafner, K and Lyon, M., (1996). Where wizards stay late, Simon Schuster, New York.

[7] Matthews, V.O., Shakunle, O.J and Adetiba, E., (2007). Hybrid cellular network for mobile networks for rural telecommunications, Res. in Physical Sci., pp 24-34.
[8] R.E. Schwartz., (1996). Wireless communications in developing countries: cellular and satellite networks, Artech house. MA: Boston.

[9] R. Conte., (1994). Rural telephony: a new appraoch usign mobile satellite communication, Pacific telemmunication conference, Honolulu: Hawai.

[10] V. Garg, K. Smolik and J.E. Wilkes., (1997). CDMA Application in wireless nets, Prentice Hall publications, New Jersey

[11] A. Salamsi and K.S. Gilhousen., (1991). On system design of CDMA applied to digital cellular and personal network, Proceedings of IEEE on Vehicular Technical Conference, pp $57-63$

[12] R.L Peterson, R.E Ziemer and D.E Borth., (1995). Introduction to spread spectrum communications, Prentice Hall publications, Upper Saddle River, NJ.

[13] R.I Pickholtz, D.L Schillings and L.B Milsten., (1982). "Theory of spread spectrum communications: a tutorial", IEEE Transactions on Communications, 30(1), pp 855 - 884.

[14] G.R Cooper and C.D McGillen., (1986). Modern communications and spread spectrum, McGraw hill publishers, NJ: Princeton.

[15] J. Rosa., (2007) "Rural telecommunications via satellite”, J. of Telecommunications, pp $75-81$.

[16] R. Conte., (1994). Rural telephony and telecommunications using mobile satellite communications, Proceedings of Pacific Telecommunication Conference, Honolulu: Hawaii.

[17] Ojugo, A., Abere, R., Orhionkpaiyo, B., Yoro, E and Eboka, A., (2013). Technical issues for IP-based telephony in Nigeria, Int. J. Wireless communications and mobile computing, $1(2), \quad$ pp 58-67, doi: $10.11648 /$ j.wcmc. 20130102.11

[18] J.N. Ofulue., (1985). Alternate source of energy for telecommunications, IEEE Proceedings on Communications, pp 87-102.

[19] European Telecommunication Standard Institute (2004). Electromagnetic compatibility and radio spectrum matters, Radio sites Engineers equipments and systems, pp 1-60.

[20] STM Wireless., "Rural telephony products" www.stm.com/rural.htm as last accessed Feb 2013. 